\title{
Effectiveness of Extension Service Delivery and Productivity of Cassava Farmers in Southwestern Nigeria
}

\author{
A. Aderinto, A. Agbelemoge and O. M Dada \\ Received: $10^{\text {th }}$ March 2016 / Accepted: $13^{\text {th }}$ July 2016
}

\begin{abstract}
Cassava production in Nigeria is limited by poor downstream activities. Effective support servicesof relevant stakeholders are critical in removing the limitations. Effectiveness of services of extension agencies as it affects productivity of cassava farmers in southwestern Nigeria was therefore examined. Multi-stage sampling technique was used to select cassava farmers from 20\% of Agricultural Development Programme (ADP) extension blocks in Oyo, Ogun and Ondo states based on intensity of cassava production. Forty percent of cassava farmers in $10 \%$ of ADP cells in selected blocks were randomly selected, producing 153, 127 and 96 respondents for the states respectively. Data obtained through interview schedule were subjected to descriptive and inferential statistics at $p=0.05$. Most respondents were males $(74.7 \%)$, married $(97.1 \%)$ and members of farmers' association (71.0\%) while 59.6\% had no formal education. Mean age was $47.9 \pm 11.79$ years, farm size $4.6 \pm 2.03 / \mathrm{ha}$, family size $6.5 \pm 0.46$ persons and farming experience $24.7 \pm 12.55$ years. Most respondents were males (74.7\%), married (97.1\%) and members of farmers' association (71.0\%) while 59.6\% had no formal education. Mean age was $47.9 \pm 11.79$ years, farm size $4.6 \pm 2.03 /$ ha, family size $6.5 \pm 0.46$ persons and farming experience $24.7 \pm 12.55$ years. Majority of the respondents had low access to extension (4.62 \pm 1.24$)$, Service effectiveness rating was low for extension (13.3 \pm 5.16$)$. Respondents considered irregular visits of extension agents (100.0\%) as the most severe constraints to utilization of services. Majority (80.9\%) recorded low productivity. Respondents' productivity was influenced by farming experience ( $\beta=$ -0.193), family size $(\beta=-0.111)$, farm size $(\beta=-0.187)$, membership of association $(\beta=0.112)$, and production capacity $(\beta=0.096$. Extension agencies were not effectively meeting the aspirations of cassava farmers. Extension agencies should therefore be more accessible and provide cassava farmers with effective support services for improved productivity.
\end{abstract}

Keywords: Stakeholders'services, Productivity, Cassava farmers, Southwestern Nigeria

\section{INTRODUCTION}

Cassava is a crop with enormous potentials. It provides a stable food base for the food need of the populace, components in livestock feeds and raw materials for industries. Cassava also seems to be recording resounding success in sub-Saharan Africa out of the numerous stories of crop intervention failures in the region. As a result of this, many African countries have embraced its cultivation with renewed vigour.

Nigeria is one of such African countries. Almost every household in rural Nigeria grows cassava on small farms as one of the staple food crop to feed families and supply the local markets. According to Fakayode et al., (2009) cassava is a very important crop to Nigeria. They noted that its comparative production advantage over other staples serves to encourage its cultivation even by the resource poor farmers. Nigeria is 
the largest producer of cassava in the world with about 40 metric tonnes per annum ahead of countries like Brazil and Thailand (Awoyinka, 2009). This figure was aggregated from small farms turning out an average of 10 tonnes per hectare. However, 10 tons/ha figure falls short of the yield potential of cassava. An average of 15-30 tonnes per hectare is attainable (Food and Agriculture Organization, FAO, 2004). The difference between actual and technically feasible yields for the crop implies great potential yet to be harnessed. In view of the growing importance and relevance of cassava in Nigeria in which there is an urgent need to increase food production and export cassava for much needed foreign exchange on a sustainable basis, it is essential to focus on increasing the yield of cassava per unit area of land. Maintaining the current level of production will limit the extent to which the numerous potentials presented by the crop could be harnessed. It is anticipated that improved cassava production will assist Nigeria in maximizing the potentials of the crop, especially for poverty alleviation, income generation and foreign exchange earnings.Awoyinka (2009) noted that Nigeria was yet to fully harness the socio-economic potentials of cassava that would translate to higher ranking of cassava next to petroleum as major contributor to the Gross Domestic Product (GDP). Adducing reason for this, Fakayode et al., (2008) submitted that cassava farms just like the other crop farms are the small scale types which are characterised by very low productivity.Increasing cassava yields from 10 tonnes to $15-30$ tonnes per ha is a significant challenge for the subsector. Push factors such as government support, new varieties, better farming practices and farmer motivation are typically cited as a means to increasing yields. Pull factors such as consumer demand, industrial demand, favourable markets, and positive attitudes are not commonly mentioned. However, it is maintained that both the 'push' and the 'pull' are needed if the industry is to move forward (IFAD, 2004). This position implies that individuals and organizations (stakeholders) whose role performances are relevant in the cassava sub-sector need to expand their capacities and be more effective in their activities. Leeuwis (2004) affirmed that an important factor influencing farmers' practices is their perception of how socio-economic environment in terms of agro-support network and inter (community) organizations was able to support them. Commenting on the situation of small scale farmers, Armando (2009) noted that the smallholder farm sector in developing countries is largely left without necessary support arrangements in infrastructure, extension services, local processing capacity, basic health care and education. Similarly, International Fund for Agricultural Development, IFAD (2004) noted that the necessary infrastructure and agri-support services to complement efforts of farmers were far from being self-evident, and even if they exist, they may not operate in a reliable way.

Extension service delivery agency is a critical stakeholder in the agricultural development of Nigeria. Agricultural extension refers to a set of organizations that support people engaged in agricultural production and facilitate their efforts to solve problems; link to markets and other players in the agricultural value chain; and obtain information, skills, and technologies to improve their livelihoods (Kristin, 2009). Government, through Agricultural Development Progamme (ADP), private agencies through agro-input dealers and associations and non-governmental agencies provide extension related services to Nigerian farmers including cassava farmers. Umali-Deininger (1997) grouped the various agencies involved in extension service delivery to farmers into three major categories viz: Public Sector Extension; Private Non- Profit Sector Extension Service Providers; Private For-Profit Sector. Farmers view extension as a form of assistance to help improve their know-how, productivity, profitability and contribution to the good of the family, community and society (Contado, 1996).In order to ensure sustainable growth in the cassava sub-sector in Nigeria, it 
is imperative to assess the effectiveness of the services rendered by different extension outfits to support the production agenda of cassava farmers. This is against the background that cassava farmers alone cannot bring about the anticipated expansion in the cassava subsector of the Nigerian agriculture. Although, farmers are at the centre of the cassava sub sector, the fact that they often depend on other services, particularly extension information implies that the success of the industry rests on the complementary services provided by the extension service providers among other stakeholders.It is against this background that this study aimed at examining cassava farmers' assessment of the effectiveness of services rendered to them by extension service providers in the study area.

\section{Objectives of the study}

The general objective of the study was to determine cassava farmers' perception of the effectiveness of services of extension service providers in relation to their productivity.

Specific objectives of the study were to:

i. describe the socio-economic characteristics of cassava farmers in the study area

ii. determine cassava farmers' access to the services of extension service providers in the study area

iii.ascertain cassava farmers' rating of effectiveness of extension service providers in the study area

iv. ascertain level of productivity of cassava farmers in the study area

v. identify the constraints militating against cassava farmers' access to services of extension service providers in the study area

\section{Hypotheses of the study}

The following hypotheses were tested:
Ho1 There is no significant relationship between cassava farmers' selected personal characteristics and their productivity.

Ho2 There is no significant relationship between cassava farmers' access to extension service providers and their productivity.

\section{MATERIALS AND METHODS}

\section{The Study Area}

The study was conducted in Southwestern region of Nigeria. The region comprises Oyo, Ogun, Ondo, Osun, Lagos and Ekiti states. The agricultural zone of the region lies between latitudes $5^{0}$ and $9^{0} \mathrm{~N}$ with an area of 114,271 square kilometers, representing $12.0 \%$ of the country's total land mass. Southwestern Nigeria is predominantly an agrarian area with rainforest and derived savannah vegetations. Agriculture is the main source of livelihood of the inhabitants of the region. Crops grown in the area include cocoa, oil-palm cashew, cassava, yam, maize and rice. Specifically the study was conducted in Oyo, Ondo and Ogun states, being the leading producers of cassava among other states in the region (Akoroda et al; 2004).

\section{Population, sampling procedure and sample size}

Cassava farmers in Southwestern Nigeria constituted target population of the study. Table 01 presents a summary of the sampling procedure and sample size. Multi-stage sampling technique was used to draw sample from ADP extension structure in states noted for intense cassava production (Oyo, Ogun and Ondo) in the region. Cassava producing ADP extension blocks in the selected states were identified: 28 for Oyo, 18 for Ogun and 15 for Ondo. Twenty percent of the identified blocks were randomly selected, resulting in six blocks for Oyo, three for Ondo and four 
for Ogun states. Extension cells in the sampled blocks were identified and $10 \%$ of them were randomly chosen, producing 6, 3 and 4 for Oyo, Ondo and Ogun states respectively. A list of cassava farmers in the selected extension cells was compiled and $40 \%$ of the identified farmers were randomly selected. This resulted in 153, 96 and 127 farmers for Oyo, Ondo and Ogun states respectively. In all, three hundred and seventy-six (376) cassava farmers constituted samples for the study.

\section{RESULTS AND DISCUSSION}

\section{Socioeconomic characteristics of cassava farmers}

Results on socio-economic characteristics of cassava farmers are presented in Table 02. The table reveals that $70.2 \%$ of the respondents were above 40 years of age with a mean age of 47.9 years. This implies dominance of middle aged farmer whose productivity may dwindle with time. Effective support services for enhanced productivity therefore become desirable and imperative. Also, $74.7 \%$ of the respondents were male. The result reveals prominence of male gender in cassava production in the study area. Based on the submission of Iheke and Nwaru (2009) who reported higher productivity in men managed cassava farms than in women's, the result implies potentials of more improved productivity with effective extension support to the farmers. Furthermore, result indicates that majority $(97.1 \%)$ of the respondents were married, while $2.9 \%$ were single. Marriage comes with responsibilities, therefore the respondents should be desirous of productivity enhancing extension support service to assist they cope with family commitments. On education, $59.6 \%$ of the respondents had no formal education. Low literacy level of the majority of respondents may limit their access to extension opportunities. Farming experience of the respondents shows a mean of 24.7 years. This is indicative of experienced cassava farmers. High experience coupled with favourable extension support is expected to have positive impact on productivity of the respondents. Mean respondents' family size was 6.5 persons. This indicates cassava farmers with fairly large family size. On farm size, result shows that majority $(73.7 \%)$ of the respondents cultivated less than 5 with a mean of 4.6ha, which is indicative of small scale farming. Resource-poor farmers should be desirous of effective extension support to increase productivity of their small farm holdings. Result on membership of social organizations reveals that majority of the farmers belonged to cassava farmers' association (71.0\%) and cooperatives $(61.7 \%)$. This implies farmers with potential opportunities to access extension support.

Table 01: Summary of sampling procedure

\begin{tabular}{cccccccc}
\hline State & $\begin{array}{c}\text { Number } \\
\text { of }\end{array}$ & $\begin{array}{c}\text { Number } \\
\text { of cassava } \\
\text { producing ADP } \\
\text { ADP } \\
\text { Blocks }\end{array}$ & $\begin{array}{c}\text { Sampled } \\
\text { ADP } \\
\text { extension } \\
\text { blocks } \\
(20 \%)\end{array}$ & $\begin{array}{c}\text { Number of } \\
\text { ADP extension } \\
\text { cells in sampled } \\
\text { extension blocks }\end{array}$ & $\begin{array}{c}\text { Sampled } \\
\text { ADP } \\
\text { extension } \\
\text { cells } \\
(10 \%)\end{array}$ & $\begin{array}{c}\text { Number of } \\
\text { cassava farmers } \\
\text { in sampled ADP } \\
\text { extension cells }\end{array}$ & $\begin{array}{c}\text { Sampled } \\
\text { cassava } \\
\text { farmers. }\end{array}$ \\
\hline Oyo & 28 & 28 & 6 & 64 & 6 & 383 & 153 \\
Ondo & 18 & 15 & 3 & 32 & 3 & 240 & 96 \\
Ogun & 20 & 20 & 4 & 43 & 4 & 318 & 127 \\
Total & 66 & 63 & 13 & 139 & 13 & 941 & 376 \\
\hline
\end{tabular}


Table 02: Distribution of respondents based on personal characteristics $(n=376)$

\begin{tabular}{|c|c|c|c|}
\hline Variable & Frequency & Percentage & Mean /Sd \\
\hline \multicolumn{4}{|l|}{ Age(years) } \\
\hline Below 31 & 44 & 11.7 & \\
\hline $31-40$ & 68 & 18.1 & 47.9 years \\
\hline $41-50$ & 82 & 21.8 & $\mathrm{Sd} \pm 11.78$ \\
\hline $51-60$ & 145 & 38.6 & \\
\hline Above 60 & 37 & 9.8 & \\
\hline \multicolumn{4}{|l|}{ Sex } \\
\hline Male & 281 & 74.7 & \\
\hline Female & 95 & 25.3 & \\
\hline \multicolumn{4}{|l|}{ Marital status } \\
\hline Single & 11 & 2.9 & \\
\hline Married & 365 & 97.1 & \\
\hline \multicolumn{4}{|l|}{ Educational attainment } \\
\hline No formal education & 224 & 59.6 & \\
\hline Primary school & 78 & 20.7 & \\
\hline Secondary school & 47 & 12.5 & \\
\hline OND & 11 & 2.9 & \\
\hline NCE & 6 & 1.6 & \\
\hline B.Sc & 10 & 2.7 & \\
\hline \multicolumn{4}{|l|}{ Farming experience (years) } \\
\hline Below 10 years & 70 & 18.6 & 24.7 years \\
\hline $10-20$ years & 101 & 26.9 & $\mathrm{Sd} \pm 12.55$ \\
\hline Above 20 years & 205 & 54.5 & \\
\hline \multicolumn{4}{|l|}{ Family size (Persons ) } \\
\hline Below 5 & 75 & 19.9 & 6.5 persons \\
\hline $5-10$ & 288 & 76.6 & $\mathrm{Sd} \pm 2.42$ \\
\hline Above 10 & 13 & 3.5 & \\
\hline \multicolumn{4}{|l|}{ Farm size hectare (ha) } \\
\hline Below 5 ha & 277 & 73.7 & 4.6 ha \\
\hline $5-10$ ha & 98 & 26.1 & $\mathrm{Sd} \pm 2.03$ \\
\hline Above 10 ha & 01 & 0.3 & \\
\hline $\begin{array}{l}\text { Membership of } \\
\text { organization* }\end{array}$ Social & & & \\
\hline Cassava farmers association & 267 & 71.0 & \\
\hline Cassava processors association & 01 & 0.3 & \\
\hline Cooperative societies & 232 & 61.7 & \\
\hline
\end{tabular}

*Multiple response

Cassava farmers' access to services of activities. Table 03 indicates that $71.8 \%$ of extension agencies the respondents sometimes accessed public extension outfit of the ADP while $84.0 \%$ and Access to extension services is important if farmers must benefit from up to date information for their agricultural production $80.0 \%$ of the respondents never accessed extension services provided by private and nongovernmental organizations. Access to ADP, 
a government extension agency implies that cassava farmers had opportunities to benefit from productivity enhancing information at little or no cost. However, lack of access to extension opportunities outside ADP source limits farmers' opportunities for information for improved productivity. This is worrisome in view of the fact that ADP is not enjoying adequate funding just like many other government agencies. Generally, majority $(74.2 \%)$ of the respondents had low access to possible extension service delivery opportunities. This is a fall out of the fact that only ADP agency was accessible to the respondents while the other equally important bodies (Private and NGO) were not impressively accessible to them. Extension service is an important ingredient in agricultural development and therefor, farmers' access to all possible avenues to secure the service at affordable terms would significantly impact on their productivity. Efforts geared toward addressing constraints to access of NGO and private agencies will be in the interest of agricultural development in general and increased farmers' productivity in particular.

\section{Cassava farmers' rating of effectiveness of extension agencies}

Extension service delivery rating as presented in Table 04 indicates that majority (76.1\%) of the respondents noted services being rendered to them to be on the low divide of effectiveness while $23.9 \%$ rated it to be high. The result derived principally from extension outfits in the study area that are not providing farmers with regular visitation, demonstrations, organization of field days and necessary linkage supports. The low effectiveness rating of extension by farmers may be a consequence of the fact that cassava farmers only sometimes accessed the available ADP supplied extension services while the private and NGO sources that are expected to bridge the gap of inadequacies of the ADP are practically not accessible to the respondents. Generally, the result implies that cassava farmers in the study area were yet to see extension services as effectively contributing to their production aspirations.

\section{Productivity of cassava farmers}

Productivity of cassava farmers derives from cost and returns in cassava production efforts of the farmers. Table 05 presents results on productivity of the respondents. The table reveals an average cassava production of 12.1 tonnes/ha. The result indicates that cassava farmers in the study area were producing below the 15-30 tons/ha yield potential of cassava (FAO, 2004). The result could be attributed to ineffectiveness of agri-support service delivery to cassava farmers, of which extension is usually at the fore front. Also, an average cost of $\mathrm{N} 127128.00$ was put into producing the 12.1tonnes/ha per hectare only to realize an average income of N97837.72/ha. This accounts for the low productivity of majority $(80.9 \%)$ of the respondents. The result brings to focus the general problem of low productivity of peasant farmers in Nigeria. Awoyinka (2009) reported that despite all human and material resources devoted to agriculture, the productive efficiency for most crops still fell under 60 percent. Low productivity may be a consequence of the inadequacy of agricultural extension support services.

\section{Cassava farmers' ranking of constraints to accessing services of extension agencies}

Table 06 presents cassava farmers' ranking of three notable constraints militating against their access and utilization of services of extension agencies in the study area. Inadequate number of Extension Agents (100.0\%) were compared with the large number of farmers as the most severe constraint limiting full exploitation of extension services. Poor timing of service delivery $(69.4 \%)$ was considered the next severe constraint while long distance to extension from the villages $(52.7 \%)$ exerted the least impediment to cassava production. 
Table 03: Distribution of respondents based on access to extension agencies

\begin{tabular}{lcccccccccc}
\hline \multirow{2}{*}{$\begin{array}{c}\text { Access to extension } \\
\text { agencies }\end{array}$} & \multicolumn{2}{c}{ Never } & \multicolumn{2}{c}{ Sometimes } & \multicolumn{2}{c}{ Always } & $\begin{array}{c}\text { Access } \\
\text { score }\end{array}$ & \multicolumn{2}{c}{ Level of access } \\
\cline { 2 - 12 } & F & $\%$ & F & $\%$ & F & $\%$ & & F & $\%$ & Category \\
\hline Public (ADP) & 9 & 2.4 & 270 & 71.8 & 97 & 25.8 & $3.0-4.5$ & 279 & 74.2 & Low \\
Private & 316 & 84.0 & 58 & 15.4 & 2 & 0.5 & & & & \\
NGO & 304 & 80.9 & 61 & 16.2 & 11 & 2.9 & $4.6-9.0$ & 97 & 25.8 & High \\
\hline
\end{tabular}

Scores: $\operatorname{Min}=3 \mathrm{Max}=9$, Mean=4.6 $\mathrm{Sd}=1.24$

Table 04: Distribution of cassava farmers based on their rating of effectiveness of services of stakeholders

\begin{tabular}{|c|c|c|c|c|c|c|c|c|c|c|}
\hline & \multicolumn{3}{|c|}{ Adequacy of service } & \multicolumn{3}{|c|}{ Timeliness of service } & \multicolumn{3}{|c|}{ Affordability of conditions of service } & \multirow{2}{*}{$\begin{array}{l}\text { Level of } \\
\text { effectiveness }\end{array}$} \\
\hline & Never & $\begin{array}{l}\text { Some } \\
\text { times }\end{array}$ & Always & Never & $\begin{array}{l}\text { Some } \\
\text { times }\end{array}$ & Always & Never & $\begin{array}{l}\text { Some } \\
\text { times }\end{array}$ & Always & \\
\hline & F (\%) & $\mathrm{F}(\%)$ & F (\%) & F (\%) & $\mathrm{F}(\%)$ & F (\%) & F (\%) & $\mathrm{F}(\%)$ & F (\%) & F (\%) \\
\hline \multicolumn{11}{|l|}{$\begin{array}{l}\text { Extension } \\
\text { agencies }\end{array}$} \\
\hline Public (ADP) & $\begin{array}{l}121 \\
(32.2)\end{array}$ & $\begin{array}{l}199 \\
(52.9)\end{array}$ & $\begin{array}{l}56 \\
(14.9)\end{array}$ & $\begin{array}{l}217 \\
(57.7)\end{array}$ & $\begin{array}{l}81 \\
(21.5)\end{array}$ & $\begin{array}{l}78 \\
(20.7)\end{array}$ & $\begin{array}{l}48 \\
(12.8)\end{array}$ & $\begin{array}{l}250 \\
(66.5)\end{array}$ & $\begin{array}{l}78 \\
(20.7)\end{array}$ & $\begin{array}{l}286 \\
(76.1) \text { Low }\end{array}$ \\
\hline Private & $\begin{array}{l}346 \\
(92.0)\end{array}$ & $\begin{array}{l}8 \\
(2.1)\end{array}$ & $\begin{array}{l}22 \\
(5.9)\end{array}$ & $\begin{array}{l}346 \\
(92.0)\end{array}$ & $\begin{array}{l}0 \\
(0.0)\end{array}$ & $\begin{array}{l}30 \\
(8.0)\end{array}$ & $\begin{array}{l}346 \\
(92.0)\end{array}$ & $\begin{array}{l}7 \\
(1.9)\end{array}$ & $\begin{array}{l}23 \\
(6.1)\end{array}$ & \\
\hline NGO & $\begin{array}{l}286 \\
(76.1)\end{array}$ & $\begin{array}{l}14 \\
(3.7)\end{array}$ & $\begin{array}{l}76 \\
(20.2)\end{array}$ & $\begin{array}{l}286 \\
(76.1)\end{array}$ & $\begin{array}{l}21 \\
(5.6)\end{array}$ & $\begin{array}{l}69 \\
(18.3)\end{array}$ & $\begin{array}{l}286 \\
(76.1)\end{array}$ & $\begin{array}{l}9 \\
(2.4)\end{array}$ & $\begin{array}{l}81 \\
(21.5)\end{array}$ & $\begin{array}{l}90 \\
(23.9) \text { High }\end{array}$ \\
\hline
\end{tabular}

Table 05: Distribution of respondents based on level of productivity $(n=376)$

\begin{tabular}{|c|c|c|c|c|c|c|c|c|c|}
\hline \multirow[t]{2}{*}{$\begin{array}{l}\text { Average } \\
\text { Yield/ha } \\
\text { (Tonne) }\end{array}$} & $\begin{array}{c}\text { Average } \\
\text { Cost } \\
\text { /ha (N) }\end{array}$ & $\begin{array}{l}\text { Average } \\
\text { Income } \\
\text { /ha(N) }\end{array}$ & $\begin{array}{l}\text { Productivity } \\
\text { index }\end{array}$ & Freq & $(\%)$ & \multirow[t]{2}{*}{$\begin{array}{c}\text { Productivity } \\
\text { score } \\
\text { Category }\end{array}$} & \multicolumn{3}{|c|}{$\begin{array}{c}\text { Level of productivity } \\
\text { Freq }(\%)\end{array}$} \\
\hline & & & $0.00-0.49$ & 105 & 27.9 & & & & \\
\hline & & & $0.50-0.99$ & 199 & 52.9 & $0.0-0.76$ & 304 & 80.9 & Low \\
\hline & & & 1.00 & 1 & 0.3 & & & & \\
\hline \multirow[t]{3}{*}{12.10} & 127128.00 & 97837.72 & $1.01-1.49$ & 47 & 12.5 & $0.77-3.33$ & & & \\
\hline & & & $1.49-1.99$ & 15 & 4.0 & & 72 & 19.1 & High \\
\hline & & & $>1.99$ & 9 & 2.4 & & & & \\
\hline
\end{tabular}

$\operatorname{Min}=0.05 \mathrm{Max}=3.33$, Mean productivity $=0.77 \mathrm{SD}=0.48$

Table 06: Distribution of cassava farmers based on rating of constraints to the use of services of stakeholders

\begin{tabular}{lclcc}
\hline & $\begin{array}{c}\text { Severity } \\
\text { ranking }\end{array}$ & \multicolumn{1}{c}{ Constraints } & Freq & $(\%)$ \\
\hline \multirow{2}{*}{ Extension } & $1^{\text {st }}$ & Irregular visits & $376(100.0)$ & 100.0 \\
service providers & $2^{\text {nd }}$ & Poor timeliness of service delivery & $261(69.4)$ & 69.4 \\
& $3^{\text {rd }}$ & Far distance of extension office to villages & $198(52.7)$ & 52.7 \\
\hline
\end{tabular}

Multiple responses allowed 


\section{Hypotheses Testing}

\section{Hypothesis one}

Ho: There is nosignificantrelationship between selected socio-economic characteristics of cassava farmers (age, sex, education, farming experience, farm size and membership of social organization) and their level of productivity.

Table 07 presents results of the test of relationship between cassava farmers' socioeconomic characteristics and their level of productivity. Results reveal that a significant relationship exists between age $\left(\chi^{2}=41.77\right.$, $\mathrm{p}<0.05)$, sex $\left(\chi^{2}=12.69, \mathrm{p}<0.05\right)$, farming experience $\left(\chi^{2}=53.18, \mathrm{p}<0.05\right)$, family size $\left(\chi^{2}\right.$
$=23.43, \mathrm{p}<0.05)$, farm size $\left(\chi^{2}=12.69, \mathrm{p}<\right.$ $0.05)$, membership of social organizations $\left(\chi^{2}\right.$ $=10.55, \mathrm{p}<0.05)$ and productivity of cassava farmers. However, result reveals no significant relationship between education and productivity of cassava farmers in the study area $\left(\chi^{2}=10.33\right.$, $p<0.05)$. This implies that level of education of cassava farmers had no influence on their level of productivity.

\section{Result of correlations between cassava farmers' access to extension agencies and their productivity}

Ho3: There is no significant relationship between cassava farmers' access to extension agencies' services and their level of productivity.

Table 07: Chi-square Analysis testing for relationship between selected socio-economic characteristics of cassava farmers and their level of productivity $(n=376)$

\begin{tabular}{|c|c|c|c|c|c|c|c|}
\hline & \multicolumn{4}{|c|}{ Farmers' level of productivity } & \multirow{3}{*}{$\chi^{2}$ value } & \multirow{3}{*}{ Df } & \multirow{3}{*}{$\mathrm{P}$-Value } \\
\hline & \multicolumn{2}{|c|}{ Low } & \multicolumn{2}{|c|}{ High } & & & \\
\hline & $\mathrm{F}$ & $\%$ & $\mathrm{~F}$ & $\%$ & & & \\
\hline \multicolumn{8}{|l|}{ Age } \\
\hline Below 31 years & 20 & 6.6 & 24 & 33.3 & \multirow{5}{*}{41.77} & \multirow{5}{*}{4} & \multirow{5}{*}{$0.00 *$} \\
\hline $31-40$ years & 55 & 18.1 & 13 & 18.1 & & & \\
\hline $41-50$ years & 70 & 23.0 & 12 & 16.7 & & & \\
\hline $51-60$ years & 126 & 41.4 & 19 & 26.4 & & & \\
\hline Above 60 years & 33 & 10.9 & 4 & 5.6 & & & \\
\hline \multicolumn{8}{|l|}{ Sex } \\
\hline Male & 239 & 78.6 & 42 & 58.3 & \multirow[t]{3}{*}{12.69} & \multirow[t]{3}{*}{1} & \multirow[t]{3}{*}{$0.00^{*}$} \\
\hline Female & 65 & 21.4 & 30 & 41.7 & & & \\
\hline \multicolumn{5}{|l|}{ Education } & & & \\
\hline No formal education & 183 & 60.2 & 41 & 56.9 & \multirow{4}{*}{3.18} & \multirow{4}{*}{3} & \multirow{4}{*}{0.37} \\
\hline Primary education & 66 & 21.7 & 12 & 16.7 & & & \\
\hline Secondary education & 34 & 11.2 & 13 & 18.1 & & & \\
\hline Tertiary education & 21 & 6.9 & 6 & 8.3 & & & \\
\hline \multicolumn{8}{|l|}{ Experience } \\
\hline Below 10 years & 35 & 11.5 & 35 & 48.6 & \multirow{4}{*}{53.18} & \multirow{4}{*}{2} & \multirow{4}{*}{$0.00^{*}$} \\
\hline $10-20$ years & 87 & 28.6 & 14 & 19.4 & & & \\
\hline Above 20 years & 182 & 59.9 & 23 & 31.9 & & & \\
\hline \multicolumn{5}{|l|}{ Family size } & & & \\
\hline Below 5 members & 46 & 15.1 & 29 & 40.3 & \multirow{3}{*}{23.43} & \multirow{3}{*}{2} & \multirow{3}{*}{$0.00 *$} \\
\hline $5-10$ members & 246 & 80.9 & 42 & 58.3 & & & \\
\hline Above 10 members & 12 & 3.9 & 1 & 1.4 & & & \\
\hline \multicolumn{8}{|l|}{ Farm size } \\
\hline Below 5 ha & 205 & 67.4 & 72 & 100.0 & \multirow{3}{*}{12.69} & \multirow{3}{*}{1} & \\
\hline $5-10$ ha & 98 & 32.2 & 0 & 0.0 & & & $0.00^{*}$ \\
\hline Above 10 ha & 1 & 0.3 & 0 & 0.0 & & & \\
\hline Membership of social & & & & & & & \\
\hline Yes & & & & & & & \\
\hline No & $\begin{array}{c}231 \\
73\end{array}$ & $\begin{array}{l}76.0 \\
24.0\end{array}$ & $\begin{array}{l}41 \\
31\end{array}$ & $\begin{array}{l}56.9 \\
43.1\end{array}$ & 10.55 & 1 & $0.001 *$ \\
\hline
\end{tabular}

\footnotetext{
$*$ Significant
} 
Table 08: Correlations between cassava farmers' access to services of stakeholders and their

\begin{tabular}{rrrr} 
Variable & r-value & p-value \\
\cline { 2 - 4 } & Access to extension agencies & 0.008 & 0.874 \\
\hline
\end{tabular}

* Correlation is significant at the 0.05 level (2-tailed).

Result of correlation in Table 08 indicates access to extension agencies as not being significantly related to productivity of cassava farmers $(\mathrm{r}=$ $0.008 ; \mathrm{p}<0.05)$. This result is a consequence of the fact that access to extension, which provides important link between farmers and other service providers, was low. Therefore farmers could not see the impact of extension agencies on their productivity.

\section{CONCLUSION}

The research concludes that only limited opportunity of public extension outfit as being

delivered by ADP was unimpressively being accessed by cassava farmers in the study area. The possible alternative opportunities that abound to bridge the gap created by ineffective public extension agencies were not presently being harnessed by cassava farmers in the study area. This has therefore resulted in cassava farmers rating services of extension agencies as not effectively contributing to their productivity. Adequate funding of the ADP for improved coverage and service delivery is recommended. Friendly policy to support private initiatives in extension delivery to compliment efforts of the public extension is also advocated.

\section{REFERENCES}

Akoroda, M. O, Sanni, Phillips T.P and Taylor D. S 2004. The Global Cassava Development Strategy. International Fund for Agricultural Development, Food and Agriculture Organisation of the United Nations, Rome p3

Armando, C.P. 2009. Agricultural Cooperatives and Farmers Organizations: Role in Rural Development and Poverty Reduction. Swedish Cooperative Centre, Agricord (network of international agro-agencies), Sweden Pp1-7

Awoyinka, Y. A. 2009.Cassava Marketing: Option for Sustainable Agricultural Development in Nigeria. Ozean Journal of Applied Science 2(2), Pp. 175-183.

Contado, T.O. 1996. Formulating Extension Policy. In Swanson B.E, Robert P.B and A.J Sofranco (eds) Improving Agricultural Extension. A Reference Manual. Food and Agriculture Organisation of the United Nations (FAO), Rome Pp 105-112.

Fakayode S. B. Babatunde, R.O. and Ajao R. 2008. Productivity Analysis of Cassava-Based Production Systems in the Guinea Savannah: Case Study of Kwara State, Nigeria. AmericanEurasian Journal of Scientific Research 3 (1): 33-39.

FAO, 2004. Online Statistical Database. Food and Agriculture Organisation of the United Nations, Rome. www.fao.org.

IFAD and FAO. 2004. The Global Cassava Development Strategy. International Fund for Agricultural Development and Food and Agriculture Organisation, Rome.p. 5-37. 
Kristin, E. D.2009.The Important Role of Extension Systems:Agriculture and Cli mate Change:An Agenda for Negotiation in Copenhagen. International Food Policy Research Institute $2033 \mathrm{~K}$ Street, NW • Washington, DC 20006-1002 • USA Focus 16• Brief 11.

Leeuwis, C. 2004. Agricultural Knowledge and Information Systems. In Leeuwis, C (ed). Communication for Rural Innovation. Rethinking Agricultural Extension. Blackwell Publishing Ltd, U.K p322. https:/doi.org/10.1002/9780470995235.ch17

Umali-Deininger, D. 1997. Public and Private Agricultural Extension: Partners or Rivals. The World Bank Research Observer, Vol 12 no 2 August 1997. https:/doi.org/10.1093/wbro/12.2.203 